\title{
A Proposed Model for Post-Pandemic Higher Education
}

\author{
Mohammad Hossein Keshavarz \\ Head of ELT Department, Girne American University, North Cyprus \\ keshavarz22@gmail.com
}

\begin{abstract}
Education is one of the main sectors that have been drastically affected by COVID-19 pandemic worldwide. In this paper, after providing a brief background about the global impact of Coronavirus pandemic on different spheres of life, the effect of COVID-19 on education, in general, and higher education, in particular, will be discussed. Then, different types of online educational models will be reviewed. Next, the advantages and disadvantages of face-to-face classroom instruction versus online education will be elaborated on. Finally, a model for postpandemic higher education will be proposed and delineated.
\end{abstract}

Keywords

COVID-19; online education; a proposed model; postpandemic; higher education

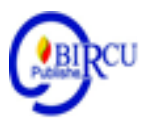

\section{Introduction}

COVID-19 pandemic has had devastating effects on all aspects of life worldwide, from economy, health, transportation, to education and personal life style. It is considered the most detrimental "global health calamity of the century and the greatest challenge that the humankind [has] faced since the 2nd World War" (Chakraborty, \& Maity, 2020, p.1). The virus spread exponentially country by country and region by region rapidly affecting all daily life, in particular global healthcare systems, economy and education. According to Nicola et al. (2020), COVID-19 pandemic has "resulted in over 4.3 million confirmed cases and over 290,000 deaths globally" (p. 185). Consequently, in reaction to the catastrophic effects of this pandemic, many countries across the globe were forced to lockdown their population, impose travel restrictions and quarantine in an effort to maintain this communicable disease.

However, despite its being a tragic human disaster, Coronavirus has taught us many valuable lessons including respect for nature and the realization that power, fame and fortune, and social status are worthless as they cannot provide us with the oxygen we fight for when we are affected by this deadly virus. Ironically, COVID-19 should, indeed, be credited for its non-racist and nondiscriminatory behavior. It has proven that it does not differentiate between heads of powerful states, like Angela Merkel, the Chancellor of Germany, and Borris Johnson, the prime minister of Great Britain, on the one hand, and homeless vagrants in those countries, on the other hand. It has also shown us that the value of a simple face mask, when badly needed, is much higher than that of the most sophisticated and advanced jet fighters and space shuttles that cost billions of dollars to manufacture. Moreover, thanks to this deadly virus, we have learned to love and care for one another, albeit at a distance, and also to love nature and preserve it for future generations so that they can live in a better world than we do. 


\section{Discussion}

\subsection{The Impact of COVID-19 Pandemic on Education}

Education is one of the main sectors that have been most drastically impacted by COVID-19 pandemic. As stated by UNESCO Director-General, Audrey Azoulay, "the global scale and speed of the current educational disruption is unparalleled and, if prolonged, could threaten the right to education" (UNESCO Press Release, 3 March 2020). This organization has declared that "close to 900 million learners have been affected by the closure of educational institutions" (Nicola et al., 2020, p. 187), as shown in Figure 1.

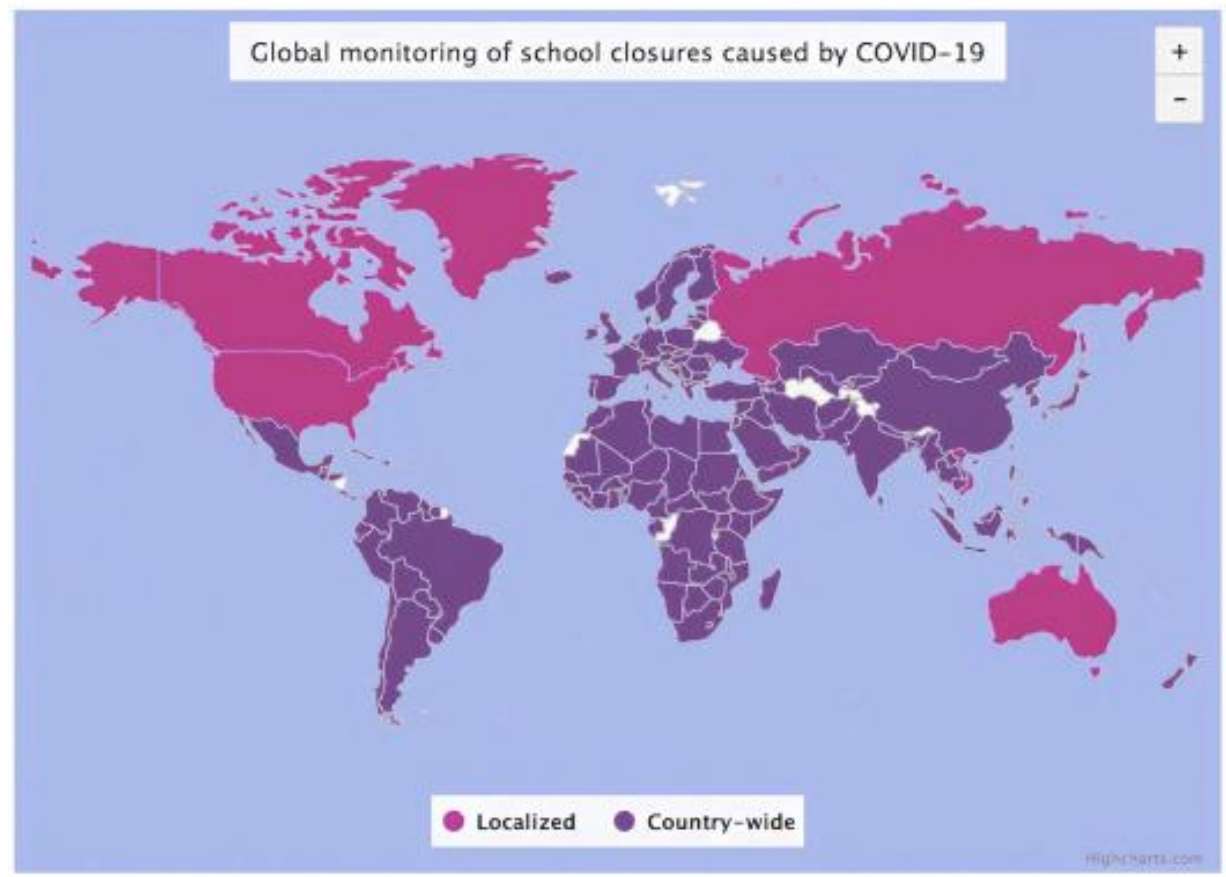

Visualize evolution over time.

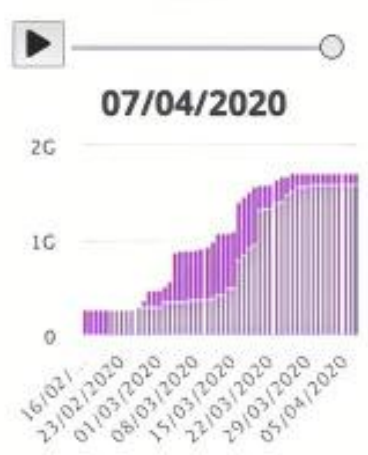

$1,576,021,818$ affected learners $91.3 \%$ of total enrolled learners 188 country-wide closures

Figure 1. Global impact of COVID-19 on school closures. Source: UNESCO (2020), reprinted in Nicola et al. (2020, p. 187)

This report was released on March $3^{\text {rd }}, 2020$, but it is obvious that with the rapid spread of Coronavirus worldwide since that time, the 900 million figure reported by UNESCO has risen considerably. According to an estimate, "as of 13 April 2020, approximately 1.725 billion learners have been affected due to school closures in response to the pandemic" (Wikipedia, April 13, 2020).

However, a valuable lesson has also been learned from COVID-19 pandemic in the realm of education, namely adaptability and flexibility in the delivery of educational materials. When universities were forced to close down in the middle of the Spring Semester as a result of Coronavirus outbreak, there was a period of confusion and uncertainty as to how to continue and end the current academic year. To mitigate the devastating impacts of this unprecedented crisis, colleges and universities across the globe hastily resorted to online teaching, in one form or another. Before elaborating further on the impact of COVID-19 on education, it deems necessary to briefly describe different types of online education. 


\section{a. Online Education}

In pre-digital age, students had only one educational option, namely to go to school in order to become literate and educated, but $21^{\text {st }}$ century students have many learning options available to them. In the past, education was centered on printed materials (books and pamphlets), teachers, and physical school setting, where students had to attend on a daily basis and rely on their teachers as the main source for information and knowledge. In the modern era, however, digital technology has revolutionized education like other aspects of our life. As stated by Silaban, Suharianto, and Ruslan (2020), “...the world of education has begun to shift the paradigm of 21st century learning from the traditional Era towards ITbased learning and the internet, so learning can be done anywhere and anytime, and also information can be obtained from anywhere" (p.88). Needless to say, the traditional teaching strategies are practical; however, with advances in educational technology, the effectiveness of traditional learning methods has become something of the past. As Wikramanayake (2014) puts it, "advances in digital technology have opened up many avenues of learning. Technology has made information accessible/ transmittable from anywhere and by/to all groups of people. Education has reached most parts of the world and ICT [Information and Communication Technology] has become an integral part of human life" (p.1). Therefore, online education has become a vital and inevitable part of higher education in many countries. The main advantage of online education is that it reaches a broad student audience. This creates a great incentive for private universities, particularly in the west, to advertise their online programs and attract thousands of students from all over the world. Other advantages of online education include its being cost-effective both for students and institutions as well as adequacy in addressing student needs for becoming autonomous and self-directed learners. It is obvious that traditional methods of teaching can no longer meet the demands of 21 st century students.

Online methods of teaching offer different options, the most popular of which are distance education, e-learning, blended learning, and online learning. A brief description of each is provided below.

\section{b. Distance Education}

As the title implies, this method of teaching and learning does not require physical presence of students on university campuses. As mentioned above, it is designed mainly by private universities to attract students from overseas as a source of revenue, or perhaps the main source of revenue. Nowadays, many universities in Europe and North America as well as Australia offer degree programs in different fields of study through distance education.

\section{c. E-Learning}

In this method of teaching and learning, instructional materials are delivered to students through the e-learning system. Students are then responsible for those materials in order to get prepared for course assessments in the form of quizzes, midterms and final exams. In this method of education, students and teachers do not meet each other face-to-face as they can only communicate and interact with one another online and through the medium of writing. A message exchange system has been designed in the e-learning system whereby students can ask their teachers questions about their courses and receive responses and assistance. However, assignments and essays are sent to the instructor via email attachments or Edmodo software. It is worth pointing out that during the Coronavirus pandemic e-learning was used in many institutions around the globe along with video-conferencing via Zoom or similar applications, even if students and teachers were on the same premise, in order to maintain mandatory social distancing. 


\section{d. Online Education}

Online education is carried out through internet using online webinar tools such as Zoom, AnyMeeting, GotoWebinar, and Google Meeting. Normally, meetings are scheduled by course lecturers in advance, then the meeting code and password are shared with students to meet in the virtual environment on the specified time. Unlike elearning, in this type of teaching and learning there is online interaction between students and instructors, and course materials are normally delivered in the form of PowerPoint slides. The main disadvantage of this type of learning is that students may face technical problems and poor internet connections, which in turn may cause anxiety and stress for them especially when they are assigned to have oral presentations.

\section{e. Blended Learning}

Since the model of education proposed here is a modified version of blended learning, it is essential to describe this model of learning first. The major difference between blended learning and other types of online education is that it combines traditional face-to-face teaching with online learning using a virtual platform. That is, instructors communicate with their students both online and offline, share course information with them, and assign them tasks (Bonk \& Graham, 2006; Garrison \& Vaughan 2008; Resien, Sitompul \& Situmorang, 2020; Techterms.com, 2018). Although some researchers have casted doubt on the effectiveness of blended learning compared to face-to-face classroom instruction (Dellana, Collins, \& West, 2000; Sonner, 1999), most studies confirm the effectiveness of this method of teaching and learning (Iverson, Colky, \& Cyboran, 2008; Lalima \& Lata Dangwal, 2017; Shepherd \& Gagne, 2001; Vamosi, Pierce, \& Slotkin, 2004). A major advantage of blended learning is that students do their assignments at their own pace anytime and anywhere (Boyd, 2010). It also offers students 24-hour online access to learning materials, and can have online collaborations with their teachers and classmates.

\subsection{Models of Education Adopted after Coronavirus Pandemic}

After the spread of Coronavirus worldwide, schools, colleges and universities resorted to online education, which was the only option for the continuation and completion of the academic year despite the fact that neither teachers nor students were fully prepared for this shift. In other words, observing social distancing enforced by governments in most parts of the world in order to maintain the health of staff and students, schools and universities were forced to switch to virtual mode of educational delivery. To teach courses online, instructors had to prepare their lessons in advance and share them with students in virtual classes, normally through slides or texts. They also uploaded related course material files on e-learning platform so that students could read the materials before attending virtual meetings. Although online teaching and learning may appeal to some students for the luxury it offers in attending virtual classes without taking the trouble of commuting to school, this is not the view shared by all students. In fact, the feedback the author has received from his students shows that the majority of them prefer and badly miss face-to-face classroom instruction and interaction with teachers and fellow students. Research findings also indicate that students have different learning styles and learning personalities, hence not all students can benefit equally and optimally from online education (Afip, 2014; Deci, Vallerand, Pelletier, \& Ryan, 1991; Gagne \& Shepherd, 2001; Keshavarz \& Hulus, 2019; Nag, 2018; Trasler, 2002; Woodill \& Officer, 2004)). Thus, there seems to be a dilemma in the choice of an effective educational model. On the one hand, the main disadvantage of traditional classroom 
teaching is that it is not flexible enough to adapt to unpredictable events like COVID-19 pandemic. It is also not compatible with modern technological advances in education, at least in many parts of the world. It is axiomatic that a good educational system should be flexible and should keep stride with modern educational technology in order to achieve optimal and satisfactory outcomes and provide a better learning environment for students and teachers alike. The worldwide pandemic, indeed, made educational policy makers realize that total reliance on traditional classroom teaching can cause a great deal of chaos and disruption in the flow of education in times of calamity.

On the other hand, total dependence on distance education programs faces some challenges and shortcomings. One of the main disadvantages of online learning is that it can never replace the live human interaction with teachers and fellow students provided by classroombased instruction, despite the fact that it offers options such as videoconferencing. As highlighted in Vygotsky's theory of social interaction and constructivism, human interaction is crucially important in our social life (Larchelle, Bednarz, \& Garrison, 1998; Moll, 2014). In educational settings, this cannot be achieved without face-to-face social interactions with fellow students and teachers (Raja Hussain, 2010).

Moreover, the self-paced nature of e-learning modules may appear as an advantage, but in reality it may lead to procrastination and laziness as opposed to the disciplined nature of classroom instruction.

\subsection{A Modified Version of Blended-Learning for Post-Pandemic Higher Education}

A way out of the dilemma outlined above seems to be a modified version of blended learning in the form of a hybrid campus, which embraces the advantages of both traditional faceto-face instruction and online learning. The major difference between the modified blendedlearning proposed herein and the original model is that to take blended-learning courses, students have to go to the campus on a regular basis to attend computer lab sessions; whereas, in the modified version, students and teachers go to school every other day or every other week depending on the arrangements made by departments and faculties since only 50\% of the total instruction is delivered through classroom teaching and the rest in virtual environment, hence a hybrid campus. With regard to the distribution of courses, they can be divided into two major categories: theoretical and practical. Theoretical courses can be easily taught online while practical courses require face-to-face instruction. However, it needs to be emphasized that this model is proposed for post-pandemic periods only. It is obvious that during pandemic and lockdown all courses have to be delivered through online education systems.

If implemented appropriately, the hybrid campus offers great advantages not only educationally, but also economically for all parties concerned, i.e., teachers, students, and universities. That is, a great deal of time, energy, and money will be saved as neither students nor teachers have to drive to school, or take public transportation to attend courses. For universities, the modified blended-learning model is cost-effective. In particular, smaller universities that face shortage of space in terms of physical classrooms can solve their problems by adopting the hybrid campus scheme instead of constructing new buildings. For instance, if two faculties share the same building and have class distribution problems, they can alternate using the building. That is, each faculty can have the whole building at their disposal every other day or every other week. The modified version and hybrid campus may also boost the admission rate of universities since applicants who have a full or part-time job may find it easier to manage and divide their time between work and school considering the flexibility that the hybrid campus offers and the fact that they can receive 50\% of instruction online.

It is also environmentally friendly. The great advantage of hybrid campuses for the environment, particularly in large cities, 1 has in include less air and noise pollution, and less traffic jam. Needless to say, such factors can cause stress, fatigue, and irritability in commuters.

From the learner's perspective, the main advantage of the model proposed here is that it 
provides variety and versatility in learning as it combines positive features of class-based instruction and online learning. This type of combinatory model is less boring and more engaging for the learners and it enhances their adaptability skills through self-coordinated style of learning.

The synthesis of classroom teaching with online education can also augment students' interest as they can effectively collaborate with their classmates and teachers, which in turn boosts their competence and confidence. The 24-hour online access to the internet in the online part of the model allows students to concentrate on their tasks and complete themduring their free time without being under stress and time pressure.

\section{Conclusion}

To recapitulate, this model has several advantages over both traditional classroom teaching and total online education. Unlike conventional classroom teaching, the modified blended-learning model is flexible, versatile, and adaptable, particularly at times of calamities and disasters. For instance, if this model was used prior to COVID-19 outbreak, teachers and students would have easily switched to online education without any disruption as they were accustomed to it. It also takes full advantage of modern educational technology, unlike traditional classroom teaching.

Additionally, it has some advantages over total online education system in a number of ways. One of the main disadvantages of online education is related to testing and assessment. Needless to say, even under normal circumstances students experience a great deal of exam anxiety. This anxiety increases substantially with online quizzes and exams both before and during the exams considering students' worries about technical problems, fear of being disconnected during the exam, and lack of flexibility in terms of time. The advantage of hybrid campus, on the other hand, is that exams can be held in the physical classroom setting with which students are familiar, hence they experience less anxiety.

The second disadvantage of total online education is that students may suffer from self-isolation and lack of communicative skills as they follow instruction from home throughout a semester or an academic year. Whereas, in the proposed model, they spend half of their time at school and benefit from face-to-face interaction with fellow students and teachers.

Thirdly, since in total online education students are on their own there is lack of discipline and inefficient utilization of time. Man by nature is lazy; therefore, in absence of discipline and time restriction, students may be too relaxed and consequently procrastinate their assignments.

Moreover, total reliance on online education requires training and experience that many students and instructors may lack. An added problem is lack of adequate infrastructure and technological facilities in many countries, where the teacher-oriented instruction is the dominant culture. This can, indeed, make online education difficult.

Finally, to protect the rights of academic and non-academic staff, universities that adopt a hybrid model should ideally consider a raise in the salary of faculty members since the amount of time and effort lecturers put into the preparation and delivery of online materials is far greater than that of classroom teaching. As an example, to prepare an online multiple-choice test one has to spend an excessive amount of time since, unlike traditional multiple-choice tests, for each item one has to repeat the same procedure as each item appears on a separate page on the e-learning platform. Likewise, the salary of non-academic staff should also be increased since in addition to their daily responsibilities on campus they may play a role in online education, as well. 


\section{References}

Afip, L. (2014). Motivating adult learners using blended learning in higher education institutions. Journal of Arts, Science \& Commerce, 5(3), 35-42.

Bonk, C.J., \& Graham, C.R. (2006). The handbook of blended learning environments: Global perspectives, local designs. San Francisco, California: Jossey, Bass/Pfeiffer.

Boyd, D. (2010). Social network sites as networked publics: Affordances, dynamics, and implications. In Zizi Papacharissi (Ed.), A networked self (pp. 47-66). London: Routledge.

Chakraborty, I., \& Maity, P. (2020). COVID-19 outbreak: Migration, effects on society, global

environment and prevention. Sci Total Environ. 2020;728:138882.

doi:10.1016/j.scitotenv.2020.138882

Deci, E., Vallerand, R., Pelletier, L., \& Ryan, R. (1991). Motivation and education: The selfdetermination perspective. Educational Psychologist, 26(3-4), 325-346. doi: 10.1080/00461520.1991.9653137.

Dellana, S., Collins, W., \& West, D. (2000). Cyber dimensions: on-line education in a management science course-effectiveness and performance factors. Journal of Education for Business, 76(1), 43-47. doi: 10.1080/08832320009599049

Gagne, M., \& Shepherd, M. (2001). Distance learning in accounting: A comparison between a distance and a traditional graduate accounting class. Technological Horizons in Education, 28(9), 58-60.

Garrison, D. \& Vaughan, N. (2008). Blended learning in higher education. San Francisco, Calif: Jossey-Bass.

Iverson, K., Colky, D., \& Cyboran, V. (2008). E-learning takes the lead: An empirical investigation of learner differences in online and classroom delivery. Performance Improvement Quarterly, 18(4), 5-18. doi: 10.1111/j.1937-8327.2005.tb00347.x

Keshavarz, M. H. \& Hulus, A. (2019). The effect of students' personality and learning styles on their motivation for using blended learning. ALLS, 10(6), 78-88.

Lalima, D. \& Lata Dangwal, K. (2017). Blended Learning: An innovative approach. Universal Journal of Educational Research, 5(1), 129-136. doi: 10.13189/ujer.2017.050116

Larchelle, M., Bednarz, N. \& Garrison, J. (1998). Constructivism and education. UK: Cambridge University Press.

Moll, Luis C. (2014 ). L. S. Vygotsky and education: Routledge Key Ideas in Education. (1st Edition). London: Routledge.

Nag, A. (2018). Personality types of learners and their effect on learning. Available at: https://blog.commlabind ia. com/elearning-design/personality-types- learners.

Nicola, M., Zaid Alsafi, Z., Sohrabi, C., Kerwan, A., Al-Jabir, A., Iosifidis, C, Maliha Agha, M., \& Agha, R. (2020). The socio-economic implications of the coronavirus pandemic (COVID-19): A review. International Journal of Surgury, 78, 185-193. doi: $10.1016 /$ j.jijsu.2020.04.018

Resien, C., Sitompul, H., \& Situmorang, J. (2020). The effect of blended learning strategy and creative thinking of students on the results of learning information and communication technology by controlling prior knowledge. Budapest International Research and Critics in Linguistics and Education (BirLE),3(2), 879-893. Available online at: www.bircu-journal.com/index.php/birle 
Silaban, Putri Sari M. J., Suharianto, J., \& Ruslan, D. (2020). Development of macroeconomic theory materials based on blended learning. Budapest International Research and Critics in Linguistics and Education (BirLE) Journal, 3(1), 88-98. Available online at: www.bircu- journal.com/index.php/birle

Sonner, B. (1999). Success in the Capstone business course-Assessing the effectiveness of distance learning. Journal of Education for Business, 74(4), 243-247. doi: $10.1080 / 08832329909601692$

Sze-yenga, F. \& Raja Hussain, R. M. (2010). Self-directed learning in a socio-constructivist learning environment. Procedia - Social and Behavioral Sciences, 9 (2010), 1913-1917. Available online at: www.sciencedirect.com1877-0428 (c) 2010 Published by Elsevier.Ltd. DOI:10.1016/j.sbspro.2010.12.423

Techterms.com. (2018). VLE (virtual learning environment) definition. Available at: https $/ /$ techterms.com/definition/vle [Accessed 22 Aug. 2018].

Trasler, J. (2002). Effective learning depends on the blend. Industrial and Commercial Training, 34(5), 191-195. doi: 10.1108/00197850210437111

Educational Disruption and Response. UNESCO (2020). Available online at: https://en. unesco.org/themes/ed ucation-emergencies/coronavirus-school-closures.

Wikramanayake, G. (2005). Impact of Digital Technology on Education. Available Online at: https://www.researchgate.net/publication/216361364 Conference Paper, August 2005

Woodill, G., \& Officer, D. C. L. (2004). Where is the Learning in E-learning?. A critical analysis of the e-learning industry (Operitel Corporation). Peterborough, Ontario, Canada: Operitel Corporation. 